\title{
Effective university teaching: views of Australian university students from low socio-economic status backgrounds
}

\author{
Marcia Devlin* and Helen O’Shea \\ Higher Education Research Group, Deakin University, Melbourne, Australia
}

(Received 31 January 2011; final version received 16 October 2011)

\begin{abstract}
As the Australian higher education population further diversifies as a result of federal government policy changes, the collective understanding of effective university teaching in the Australian context will need to evolve to incorporate such shifts. The Australian Government has set clear targets for increased university participation of people from low socio-economic status (LSES) backgrounds. While their performance is comparable to students from higher SES backgrounds, many LSES students face particular challenges in undertaking university study. Using a 'success-focused' (Devlin 2009) methodological approach, this research documents the factors that a sample of 53 later-year, LSES students at one Australian university report have assisted them to manage and overcome the challenges of remaining at, progressing through and succeeding in their studies. The most helpful factors included teacher availability to help, their enthusiasm and dedication; and their effective communication with students particularly but not exclusively around assessment requirements.
\end{abstract}

Keywords: effective university teaching; low socio-economic status (LSES); widening participation; university study success; success-focused research

As the Australian higher education population further diversifies as a result of federal government policy changes, the collective understanding and practice of effective university teaching in the Australian context will need to evolve to incorporate such shifts.

Over the past two decades, successive Australian governments have recognised the poor higher education participation rates of students from low socio-economic (LSES) backgrounds. Yet, as Devlin notes, 'despite an expansion of participation per se, the provision of financial and other support for students, and significant target setting and monitoring of universities' performance' (Devlin 2008, 1), participation rates for LSES students have remained at around 15\%, compared to the current $25 \%$ for the general population (Bradley et al. 2008, 28; DEEWR 2009, ii).

The Australian Government's response to the 2008 Bradley Review of higher education (Bradley 2008) has been to set in place clear targets around increased university participation from people from LSES backgrounds. In particular, the government has announced an expectation that by the year 2020, 20\% of undergraduate enrolments should consist of people from LSES backgrounds.

*Corresponding author. Email: mdevlin@deakin.edu.au 
While their performance at university is comparable to that of students from higher SES backgrounds (Marks 2007), students from LSES backgrounds face particular challenges in undertaking university study (Devlin 2010). Many LSES students are the first in their family to attend university or in the first generation of their family to attend university. Collier and Morgan $(2008,442)$ argue that first-infamily university students 'typically possess relatively lower levels of college student expertise, in that, they cannot rely on parental advice to help them identify and resolve role-based problems or to help them understand the university's expectations'. They add that these students 'come to the university with less understanding of student roles and less capacity to build their existing knowledge into genuine expertise' (2008, 442). In contrast, students who arrive at university with a greater understanding of the role of a university student have an important resource for understanding and meeting expectations (Collier and Morgan 2008).

To achieve the successful participation of LSES students, the collective understanding and practice of effective university teaching in the Australian context will need to evolve to incorporate their particular needs. It will need to go beyond what Billingham (2009) terms the 'deficit model' of supporting non-mainstream students. Bowl (2001) identifies similar institutional barriers in proposing that (in UK universities) 'the onus seemed to be on the students to adapt themselves to the institution and its rules, rather than on the institution and its main players to adapt in response to the fresh perspectives which participants brought with them' (2001, 157). Tett (2004) similarly advocates changing the educational culture rather than the students.

The current research sought to gather information about the student experience from the point of view of LSES students who had been successful. Drawing on the work of Devlin (2009), the present study deliberately adopted a 'success-focused' approach, that is, the study was designed to uncover 'what works' for students from LSES backgrounds, rather than to focus on obstacles and problems.

Many thousands of students from LSES backgrounds have succeeded at university. The present study sought to uncover and document the factors that contributed to that success for one group of such students. For the purposes of the study, 'successful' was defined as having achieved sufficient results to have progressed beyond the first year of study. The particular challenges for first year students are well documented, as are issues of retention in and attrition from first year (see, e.g. Kift 2009). The present research was underpinned by the assumption that a student who had at least managed to pass their first year of university study and continue into a second year was a 'successful' student.

This study sought to determine student views on what factors had contributed to their retention and to their progress through their course. The central aim of the research was to uncover and highlight strategies, initiatives and knowledge that contributed to success and document these. The overall results of the study are discussed elsewhere. This paper focuses on the responses related to teachers and teaching.

Effective higher education teaching is a 'contested concept' (Skelton 2004, 452) with varying definitions. Numerous attempts have been made to identify these characteristics from various disciplinary standpoints (McMillan 2007) and from the student point of view (Vulcano 2007). However, as Devlin and Samarawickrema 
(2010) point out, there is no universally accepted definition of effective university teaching (Johnson and Ryan 2000; Paulsen 2002; Trigwell 2001).

Devlin and Samarawickrema (2010), however, suggest that effective teaching is broadly understood as teaching that is oriented to and focused on students and their learning; that it meets the requirements of the context in which it occurs (Devlin 2007) that it requires a set of particular skills and practices as identified by research (Penny 2003). Following a review of the relevant literature and a comparison between the dimensions of effective teaching reflected in the literature and the proxy measures of effective teaching used by the Australian Learning and Teaching Council (ALTC), (Devlin and Samarawickrema 2010) conclude that 'The relationship between the ALTC criteria and the validated dimensions of effective teaching from the peerreviewed literature appears strong' (118). The first four of the five ALTC criteria are: (1) Approaches to teaching that influence, motivate and inspire students to learn; (2) Development of curricula and resources that reflect a command of the field; (3) Approaches to assessment and feedback that foster independent learning; and (4) Respect and support for the development of students as individuals. These four criteria are used as a summary list of effective university teaching for the purposes of this paper. The fifth ALTC criterion refers to the scholarship of teaching and is not considered in this paper.

The present study sought to generate information about the ways in which particular teacher actions and attributes had assisted successful students from LSES backgrounds to progress through their course.

\section{Method}

This study drew on interviews with a sample of students from LSES backgrounds who were first-generation university students and who had progressed to at least their second year of university enrolment. This meant the sample included full-time and part-time students, student studying on campus and off campus and students in all course years.

\section{Measuring low economic status}

Currently in Australia, the socio-economic status of higher education students is measured using the Australian Bureau of Statistic (ABS) Index of Education and Occupation. One of four indexes developed by the ABS to measure and rank geographical areas according to SES, this index includes Census variables relating to educational attainment, employment and vocational skills (DEEWR 2009). These geographical areas are identified by the postcode of students' home address.

There are, however, widespread concerns about the effectiveness of this metric in identifying low economic status. Federal level discussions about the refinement of the definition and measurement of LSES status have begun in Australia (DEEWR 2009) but a new measure has not yet been finalised. The present study adopted the official determinant of socioe-conomic status-the postcode of the student's home addressand added a second measure, the educational attainment of parents. Students who had a parent with university level education were excluded from the sample. Only students who were both from a LSES postcode and in the first generation of their 
family to attend university were included in the study. This combined measure provided greater confidence that interviewees were from LSES backgrounds.

\section{Participants}

The first step in recruiting participants in the study was to obtain a database from the university's Planning Unit listing students who had enrolled at the university in 2010 after having successfully completed at least one year of part-time or full-time study and whose home addresses had postcodes that the Australian Bureau of Statistics (2010) identified as indicating LSES status, using the Index of Education and Occupation. The database listed 2053 students who met these requirements. The number of potential interviewees was reduced to 2047 when six students with overseas term addresses were removed.

The second step was to check students' email addresses using email verification software. Personal email addresses were used as these were determined that potential interviewees would respond more quickly than to their institutional addresses. This process reduced the number of potential study participants to 1672. This list was randomly divided into two batches to assist in administration of the recruitment email.

The third step was to send the recruitment email to the first 1025 students in May 2010, avoiding the typical assignment submission and exam periods. One hundred and twenty-eight students agreed to participate in the study. Subsequently, two students, both professionals living in remote areas, informed the researchers that they were not of LSES status and both removed themselves from the sample.

In the fourth step, the first 100 respondents to reply were recruited to the study and interview times were arranged over the following three weeks. Interviews were held face-to-face at three campuses of the university and over the telephone throughout May and in early June 2010. A number of potential interviewees then withdrew or were unable to go ahead with scheduled interviews for a range of reasons related to employment, study and personal circumstances. Eighty-one of the original 100 students in the cohort were interviewed: 30 from Campus A; 15 from Campus B, three from Campus $\mathrm{C}$; and 33 students who were studying off campus.

In the final step, the second criteria of being first-generation university students was ascertained, at the interview stage, when participants provided information on the highest level of education of each of their parents; and whether the participant was the first person in the family to go to university. This process reduced the final number of participants to 53 students: 17 from Campus A; eight from Campus B; one from Campus $\mathrm{C}$; and 27 students who were studying off campus. The interviews were digitally recorded. Each audio file was labelled with an identification code together with a date and interviewer initials. These files were uploaded to a safe shared server location to enable transcribing. HyperRESEARCH qualitative data analysis software was used to analyse the data and to identify recurring dominant themes.

\section{Interview schedule}

The interview schedule included three main questions and additional prompts (see Appendix 1). Students were asked to nominate convenient times for interviews scheduled over a three-week period. Face-to-face interviews were conducted in a 
university office, while off-campus students were interviewed by telephone. Interviews averaged 30 minutes in length.

\section{Results and discussion}

Students were asked to report on factors that had helped them to succeed in their university studies. Table 1 lists the most frequent responses overall.

The overall results in Table 1 are outlined here to provide context for the detailed findings on teaching on which the current paper focuses. A broader discussion of the overall findings in all areas of student responses can be found in Devlin and O'Shea (2011).

Table 2 provides the most frequent responses given by interviewees that were related to teachers or teaching specifically. These include both responses to the general open questions about what had helped them to succeed, as well as responses to prompts about whether particular teachers or teaching styles had been helpful, what had helped them on assessment tasks, and the most helpful person, service or thing (see Appendix 1).

The data in each of the five categories in Table 2 is discussed below.

Table 1. Most frequent responses.

\begin{tabular}{lc}
\hline Category & No. (\%) of participants \\
\hline Student motivation & $41(77 \%)$ \\
Teacher availability/approachability & $39(74 \%)$ \\
Student time management & $38(72 \%)$ \\
Family attitude & $37(70 \%)$ \\
Online discussion forum & $34(64 \%)$ \\
Using library services & $33(62 \%)$ \\
Online learning facility & $32(60 \%)$ \\
Student application/perseverance & $29(55 \%)$ \\
Teacher dedication/enthusiasm/rapport & $27(51 \%)$ \\
Teacher communication skills & $26(50 \%)$ \\
Communicate with teachers & $24(45 \%)$ \\
Friends' academic help & $23(43 \%)$ \\
Unit guide & $20(38 \%)$ \\
Study group or partner & $19(36 \%)$ \\
Teacher explains assessment requirements & $19(36 \%)$ \\
Scholarship or government allowance & $19(36 \%)$ \\
Family financial support & $18(34 \%)$ \\
Attend classes & $17(32 \%)$ \\
Communicate with other students & $17(32 \%)$ \\
Study skills & $17(32 \%)$ \\
Study strategy & $17(32 \%)$ \\
Teacher promptness & $15(28 \%)$ \\
Student maturity & $15(28 \%)$ \\
Employer flexibility & $15(28 \%)$ \\
Friends attitude & $15(28 \%)$ \\
\hline &
\end{tabular}


Table 2. Most frequent categories of responses related to teachers/teaching.

Teacher/teaching category No. $(\%)$ of participants

Available to help/approachability

$39(74 \%)$

Enthusiasm/dedication and rapport with students

$27(51 \%)$

Communication skills

$26(49 \%)$

Clarifies assessment requirements

Promptness

$15(28 \%)$

\section{Availability to helplapproachability}

As Table 1 indicates, the most frequent teacher attribute reported as helpful by the students was teacher availability to help and/or approachability. Thirty-nine of the 53 LSES students interviewed (74\%) mentioned this factor as helpful to their learning. The literature on effective teaching also highlights student-teacher contact, which is the first of Chickering and Gamson's (1987) principles of good undergraduate teaching. In Collier and Morgan's study, first-generation students were uniquely concerned about student-teacher contacts $(2008,438)$ in terms of how approachable they perceived their teachers to be. Participants in their study agreed that it was essential to improve faculty-student communication in order to increase the likelihood of student success' (2008, 434).

Illustrative examples of comments categorised here include:

I think if you have a lot of questions you can ask them easily. They are easy to approach ... and ... if you are after more than what is being taught, you can approach them, and they will expand on the subject for you. (013)

I think it goes back to support, more so of tutors, if you have ever got a drama, being able to talk to them whenever, and it's always good, tutors always give you some sort of contact to them, so they make you feel like you are never going to be a burden on them, even if it's the most obvious question you have got, even if you have the answer in front of you, if you need to know they are always welcoming to help you out. (019)

The following comments point to how a teacher's availability and/or approachability contributes to students' understandings of the expectations of them, particularly in relation to assessment tasks. These comments were also coded as 'Clarifies assessment requirements', a category that includes both unsolicited explanations and responses to students' questioning as a result of teacher availability.

Being able to approach my lecturers, that's probably a major thing. Some lecturers I felt like I couldn't approach, but the ones I could approach I feel like I was able to get a better reading on what they expected, and that's been able to help me. (036)

A small number of comments indicated an exceptional level of availability by staff, for example:

... the ... lecturer, she even called at the start of the semester ... she phoned to see that I was all right with all of the course materials, and found out if I'd thought about what my first assignment was, gave me some ideas on where to get further information that would help me with it, which was really helpful, and she said 'Anytime, you can call if you need any help...' (060) 
These comments corroborate Collier and Morgan findings that first-generation students in particular require clarity and explicitness in explanations of course requirements and were almost exclusively reliant on information directly from their teachers and that they want more detailed information, particularly regarding assignments, than traditional students $(2008,437)$. The findings here indicate that teacher availability and approachability and the willingness of the teacher to provide guidance about these expectations is the most important contributing factor to their success for this sample of LSES students.

\section{Enthusiasm/dedication and rapport}

The second most frequent category of response related to teachers/teaching was 'enthusiasm/dedication and rapport with students'. Twenty-seven of the 53 students $(51 \%)$ mentioned this factor as helpful to their learning. This finding is in accordance with the literature in the area, which indicates clearly that enthusiasm is an oft-cited characteristic of effective teachers (see Devlin and Samarawickrema 2010; Hativa et al. 2001; Kember and McNaught 2007; Marsh 1994; Marsh and Roche 1994). Kinnear $(2008,11)$ links teacher enthusiasm with enhanced student progression.

Some of the typical comments categorised here included:

[The lecturer is] really fantastic. She's just passionate, she makes it interesting ...(047)

[A lecturer] who actually wants to teach, like they actually care what they are doing, they are not just there for a job. (033)

They were both really friendly, easy-to-get-along-with type lecturers, and they sort of bridged the gap between the lecturer down the front and the 'you' as a student up the back. (021)

These comments indicate students perceived and benefited from their teachers' commitment to teaching and to learning. One student noted their teacher's significant commitment to them as an individual:

Even when I was the only student at an eLive [online] session, he continued the session with me as the only student. So he dedicates his time to that. (086)

The impact of lecturer enthusiasm, dedication and/or rapport on students and their learning can be remarkable as one student explained,

[The lecturer's] style of teaching was so inspiring. He created a voracious appetite for learning in me. (088)

\section{Communication skills}

Teacher communication skills were reported by 26 of the 53 students (49\%) as important. Comments indicated a range of aspects of communication that students valued: from making learning fun to integrating conceptual material with 'realworld' examples and otherwise making effort to communicate about the material with students. 
Definitely, the teachers that actually ... refer to the slides but they explain things in their own words as well, they are the best lecturers. You get some that just literally read what is on the slides, and it's kind of like, 'Well, I could just read that', whereas half of them start explaining it and put it into real-life context and that sticks in my head a lot better than just reading the slides. (025)

One particular teacher that we have, when they give a lecture they're very specific to giving examples that relate to say Uni students or under-grad students. Like say going out on a weekend opposed to something sort of boring that you'll kind of forget about. (100)

Some comments highlighted the importance of teachers' use of everyday, transparent language to scaffold students' understanding of discipline-specific terminology and concepts:

[These two lecturers] put everything into language you can understand, even when it's something that's quite difficult. (049)

My tutor's been really, really good when I ask simple questions, just putting it in simple terms for me if I'm struggling to understand something. (100)

\section{Clarifies assessment requirements}

Nineteen of the 53 students (36\%) referred to teachers' clarifications of assessment requirements as helpful to their success. The following were typical comments:

I think really clear instructions are always good. I think a marking guideline is very helpful... And some of [the lecturers] are really good at explaining what they want and you can put your assessment around that, whereas others, you still feel a bit vague until you get back your first assignment and then you've sort of lost, potentially lost, a lot of marks. (069)

I think, not just the task itself, but actually information around how to go about the particular task... [such as] a detailed overview of how the assessment will be structured ... is always helpful...(079)

Some students found examples of successful assessment tasks and formats particularly helpful:

One of the most helpful things I found is, they pulled out a series of pages that had examples, particularly in how you present your assignment, ... [including] 'What do you use double quotes... [and] single quotes for?' And examples of each, listed all the fonts, the margins, spacing, the paragraph spacing, double lines, ... so that every time when I do an assignment I go back and I refer to that and I double-check every single thing that I do ...(096)

What really helps sometimes is when lecturers put up examples of ... the type of work that they're looking for... That actually helps, because... you have actually got a bit of a template to follow...(099)

The students quoted here were concerned about being fully informed as to the academic requirements of them: content, structure, format and marking criteria. Their comments reinforce the importance of teacher availability and approachability 
discussed above and corroborate research identifying LSES university students' unfamiliarity with the student role and its academic expectations (Collier and Morgan 2008; Devlin 2010; James et al. 2010). Their comments also suggest that students themselves are aware of this deficit and its consequences in terms of lost time ('you know the amount of time that saves is just incredible') or lost marks ('you've sort of lost, potentially lost, a lot of marks'). The dilemma of 'trying to work it out for yourself' is summed up by this student's remarks:

What helps as well is they've given you a bit of an outline, a little bit more guidance on what they want from your assignment, as in, 'These are the things, the headers that we'd like you to cover', so you've got a little bit of a work plan... It just gives you a little bit more idea of ... what they're looking for...(061)

Each of these cases exemplifies the need to establish, at the outset, clear rules of what is expected from students in order to develop confident learner identities and behaviours, which Hockings identifies as one of the key principles of inclusive learning and teaching in higher education (Hockings 2010, 47).

\section{Promptness}

Finally, 15 of the 53 students cited the importance of their teachers' promptness in responding to their queries. Typical responses included:

[Subject coordinators have] been really accessible and they have a quick turnaround to your enquiries.... a lengthy delay is really stressful. So getting those answers promptly and being able to talk through things is really good. (082)

If I email [my tutors] I usually get a response within a day or the next day. It helps me in achieving the grades that I want...(017)

A number of comments about promptness related specifically to the online environment and/or Learning Management System (LMS):

[The LMS] is very helpful, the discussion line can be helpful, especially if the tutor's on the other side and you can get immediate feedback. (020)

Last semester, for one of the subjects there was a teacher that used to come online every now and then in the evening... and help us with the assignments. And that was absolutely fantastic, because if I had posted a question it was basically answered within 20 minutes and I could straight away move forward ...(020)

While prompt feedback and responses from staff might well be appreciated in many contexts, and is one of Chickering and Gamson's (1987) principles of good undergraduate teaching, it should be noted that the university at which this study was undertaken operates a trimester system with three 10 or 11 week teaching periods per year. This means that the timelines for all aspects of teaching and assessment are condensed and that prompt responses and feedback are critical to students successfully progressing through their study. 


\title{
The impact of teachers and teaching on LSES students
}

When asked to indicate to whom or what they would give an award for helping them most as a student, the most frequent response was one or more lecturers or tutors, or 'the lecturers' in general. A typical response:

She's a lecturer, and I had her for my very first first-year subject and it was probably from her and her input and her help and support that's enabled me to continue on. Right from the word go having someone that helpful to start with was really good. (096)

These most highly appreciated teachers exhibit multiples of the attributes and practices that students found helped them succeed in their studies: they were enthusiastic, dedicated, communicated well, were available to help and did so promptly and explained the course requirements clearly. This does not mean compromising on academic standards; indeed, some students identified intellectual challenge as contributing to their success, agreeing with Hocking's principle of maintaining 'high expectations of all students' (Hockings 2010, 46) and Chickering and Gansom's (1987) principle of communicating high expectations.

\begin{abstract}
There's been certain lecturers along the way who have just been very inspiring. . . . they're actually challenging you to think (069)

Two particular [lecturers] come to mind that they were actually tougher in terms of the way they marked and the way that they spoke to you. They didn't spoon-feed you the information and I actually like that, because it makes you learn more. (025)
\end{abstract}

\section{Implications for teaching}

It might be tempting to interpret the results of this study as indicating that students from low socio-economic backgrounds warrant no special attention or adaptations in terms of teaching and learning. The results of this study appear to fit with what the literature, and the ALTC criteria, say about effective teaching generally. As mentioned earlier, the ALTC criteria are: (1) Approaches to teaching that influence, motivate and inspire students to learn; (2) Development of curricula and resources that reflect a command of the field; (3) Approaches to assessment and feedback that foster independent learning; and (4) Respect and support for the development of students as individuals. The notion of approachability and willingness to help students identified in this study fits with ALTC criterion 4, that is, respect and support for students. The finding in the present study that teachers' enthusiasm and dedication was helpful equates to ALTC criterion 1, having influential, motivating, inspiring approaches to teaching. The finding about communication skills here correlates with a combination of ALTC criteria 1 and 3 and the importance of clarifying assessment criterion corresponds directly to ALTC criterion 3 . The finding in relation to promptness may be one that is emerging as a student expectation in a new world of super-fast, technology-enabled communication.

However, in light of Collier and Morgan's (2008) work outlined earlier and the fact that students from LSES backgrounds often do not have the cultural and social capital of students from higher socio-economic backgrounds, the findings might also be interpreted as indicating particular foci on: unpacking academic discourses and expectations; high quality interpersonal interactions about these expectations; and 
ensuring high standards are necessary for effective teaching of students from LSES backgrounds. The findings from this study cut across these three dimensions. Overall, the findings indicate that students find teachers who pay attention to their learning needs and speak to these needs in language students can understand, while maintaining academic challenge, are the most helpful to them and their learning. While it could be argued that this is just effective teaching per se, it could be equally argued that this is effective teaching with particular emphases that LSES students need and value. Future research might assist in further exploring this hypothesis.

\section{Conclusion}

There are some limitations of this study that warrant consideration. The sample was small and relied on voluntary participation. Both characteristics limit the generalisability of the findings (Gay and Airasian 1992). Further, Marsh and Dunkin (1992) point out that those who volunteer for a research project may be more highly motivated than others who do not. It may be that the results of the study are only applicable to those LSES, first-generation university students at the university with high motivation for learning.

However, despite these limitations, this research has provided insight into the LSES student view on what constitutes effective university teaching. The research has demonstrated that characteristics of the teacher in terms of their interpersonal relations with students and their skill in unpacking and explaining academic requirements and expectations are the most valued aspects of teaching for these students.

This study has also used a 'success-focused' methodology to document 'what works' for LSES students in Australian higher education. Such an approach produces a valuable evidence base to guide policy and practice development and improvement at Australian universities as the sector moves into the post-Bradley era. It is critical that proactive work such as that presented here is undertaken on a larger scale. As Tinto (2007) has argued, access without support is not opportunity and as Devlin (2010) notes, it would be 'a moral and economic tragedy' (np) to attract LSES students to university in Australia without having made the changes to teaching necessary to facilitate their success. This risk is beginning to be recognised in Australia with the award of a national grant to examine effective teaching and support of LSES students just one example of the growing awareness of the preparation required.

\section{Acknowledgements}

We would like to thank Deakin University for the provision of a Strategic Teaching and Learning Grant to fund this research and our colleagues Anna Lichtenberg, Judy Nagy, Pauline Hagel and Susie Macfarlane for their contributions to the research and paper.

\section{References}

Australian Bureau of Statistics (ABS). 2010. SEIFA: Socio-economic indexes for areas. http:// www.abs.gov.au/websitedbs/D3310114.nsf/home/Seifa_entry_page (accessed January 21, 2011). 
Billingham, S. 2009. Diversity, Inclusion, and the transforming student experience. Paper presented at the 18th European Access Network Annual International Conference, June 22-24, in York. http://www.eanedu.org/index.php?option =com_content\&view = category \&layout $=$ blog\&id $=39 \&$ Itemid $=75$ (accessed January 21,2011$)$.

Bowl, M. 2001. Experiencing the barriers: Non-traditional students entering higher education. Research Papers in Education 16, no. 2: 141-60.

Bradley, D. 2008. Review of Australian higher education. Canberra: Department of Education, Employment and Workplace Relations.

Chickering, A.W., and Z.F. Gamson. 1987. Seven principles for good practice in undergraduate education. American Association of Higher Education Bulletin 39, no. 7: 3-7.

Collier, P.J., and D.L. Morgan. 2008. 'Is that paper really due today?': Differences in firstgeneration and traditional college students' understandings of faculty expectations. Higher Education 55, no. 4: 425-46.

Department of Education, Employment and Workplace Relations. 2009. Transforming Australia's higher education system. Canberra, Australia: Australian Government. http://www.deewr.gov.au/HigherEducation/Review/Pages/default.aspx (accessed January 21, 2011).

Devlin, M. 2007. Improving teaching in tertiary education: Institutional and individual influences. Keynote address delivered at the Excellence in Education and Training Convention, August 31, in Singapore Polytechnic in Singapore.

Devlin, M. 2008. Submission to the Review of Australian higher education. Department of Education, Employment and Workplace Relations. http://www.deewr.gov.au/Higher Education/Review/Pages/Submissions.asp (accessed January 21, 2011).

Devlin, M. 2009. Indigenous higher education student equity: Focusing on what works. Australian Journal of Indigenous Education 38: 1-2.

Devlin, M. 2010. Non-traditional university student achievement: Theory, policy and practice in Australia. Keynote address delivered at the 13th Pacific Rim First Year in Higher Education Conference, June 27-30, Adelaide, Australia.

Devlin, M., and H. O'Shea. 2011. Directions for Australian higher education institutional policy and practice in supporting students from low socioeconomic backgrounds. Journal of Higher Education Policy and Management 33, no. 5: 529-35.

Devlin, M., and G. Samarawickrema. 2010. The criteria of effective teaching in a changing higher education context. Higher Education Research and Development 29, no. 2: 111-24.

Gay, L.R., and P. Airasian. 1992. Education research, 7th ed. New Jersey: Merrill Prentice Hall.

Hativa, N., R. Barak, and E. Simhi. 2001. Exemplary university teachers: Knowledge and beliefs regarding effective teaching dimensions and strategies. Journal of Higher Education 72: 699-729.

Hockings, C. 2010. Inclusive learning and teaching in higher education: A synthesis of research. York, UK: The Higher Education Academy. http://www.heacademy. ac.uk/resources/detail/ourwork/evidencenet/Inclusive_learning_and_teaching_in_higher_ education_synthesis (accessed January 21, 2011).

James, R., K. Krause, and C. Jenkins. 2010. The first year experience in Australian universities: Findings from 1994 to 2009. Canberra, Australia: Department of Education, Employment and Workplace Relations.

Johnson, T.D., and K. Ryan. 2000. A comprehensive approach to the evaluation of college teaching. New Directions for Teaching and Learning 83: 109-23.

Kember, D., and C. McNaught. 2007. Enhancing university teaching. London and New York: Routledge.

Kift, S. 2009. Articulating a transition pedagogy to scaffold and to enhance the first year student learning experience in Australian higher education. Final report. Australian Learning and Teaching Council. http://www.altc.edu.au/resource-first-year-learning-experience-kift-2009 (accessed January 21, 2011).

Kinnear, A. 2008. Diversity: A longitudinal study of how student diversity relates to resilience and successful progression in a new generation university. Edith Cowan University and Australian Learning and Teaching Council. 
Marks, G.N. 2007. Completing university: characteristics and outcomes of completing and noncompleting students. Longitudinal Surveys of Australian Youth, Research Report 5. Melbourne: Australian Council for Educational Research.

Marsh, H.W. 1994. Students' Evaluation of Educational Quality (SEEQ): A Multidimensional Rating Instrument of Students' Perceptions of Teaching Effectiveness. Self Research Centre: University of Western Sydney.

Marsh, H.W., and L.A. Roche. 1994. The use of students' evaluations of university teaching to improve teaching effectiveness. Canberra: Australian Government Publishing Service.

Marsh, H.W. and M.J. Dunkin. 1992. Students' evaluations of university teaching: A multidimensional perspective. In Higher education: Vol. 8. Handbook on theory and research, 143-234. New York: Agathon.

McMillan, W.J. 2007. 'Then you get a teacher': Guidelines for excellence in teaching. Medical Teacher: International Journal of Medical Education 29, no. 8: 209-18.

Paulsen, M.B. 2002. Evaluating teaching performance. New Directions for Institutional Research 114: 5-18.

Penny, A.R. 2003. Changing the agenda for research into students' views about university teaching: Four shortcomings of SRT research. Teaching in Higher Education 8, no. 3: 399-411.

Skelton, A. 2004. Understanding 'teaching excellence' in higher education: A critical evaluation of the National Teaching Fellowships Scheme. Studies in Higher Education 29, no. 4: 451-68.

Tett, L. 2004. Mature working-class students in an 'elite' university: Discourses of risk, choice and exclusion. Studies in the Education of Adults 36, no. 2: 252-64.

Tinto, V. 2007. Access without support is not opportunity. Presentation at the Centre for the Study of Students, University of Toronto. http://css.oise.utoronto.ca/UserFiles/File/VTinto_ presentation.pdf (accessed January 21, 2011).

Trigwell, K. 2001. Judging university teaching. International Journal for Academic Development 6, no. 1: 65-73.

Vulcano, B.A. 2007. Extending the generality of the qualities and behaviours constituting effective teaching. Teaching of Psychology 34, no. 2: 114-7.

\section{Appendix 1. Interview schedule}

1. Can you tell me about some of the things that have helped you to learn while you have been a student at [the university]?

2. Have there been particular aspects of your experience at uni that have helped you to get through units?

3. What else has helped you succeed at [the university]?

Prompts:

4. Are there particular teachers or teaching styles that have been more helpful than others?

5. What has helped you do well in assessment tasks?

6. Are there people in your life who have been helpful? Who? How have they been helpful?

7. Are there aspects of your financial arrangements or circumstances that have made things easier for you to study?

8. Are there student or other services that have assisted you to succeed at uni?

9. If you had to give an award to a person, service or thing that has helped you most as a student at [the university], who or what would it be?

10. If you had to give advice to a student (from your old school/home town/suburb/area) coming to [the university] about succeeding as you have done, what would you suggest to them?

11. Is there anything else you'd like to tell me about how you have succeeded as a student at [the university]? 
Copyright of Teaching in Higher Education is the property of Routledge and its content may not be copied or emailed to multiple sites or posted to a listserv without the copyright holder's express written permission.

However, users may print, download, or email articles for individual use. 